\title{
Peran Laporan Keuangan Dan Sistem Pengendalian Internal Terhadap Optimalisasi Penyusunan Anggaran Dana Desa Di Kabupaten Boyolali
}

\author{
Dhian Andanarini Minar Savitri, S.E., M.M. ${ }^{1)}$ \\ dhian@stietotalwin.ac.id ${ }^{1)}$ \\ Dian Kurniasari, S.E., M.Si. ${ }^{2}$ \\ ${ }^{2)}$ dian@stietotalwin.ac.id \\ Sekolah Tinggi Ilmu Ekonomi Totalwin Semarang
}

\begin{abstract}
Abstrack
This research aims to analysize the effect of financial statement and internal control system on financial management of village budgeting through accountability financial statement of village as a intervening variable. The results show that financial statement presentation and accessibility of financial statement has not effect on financial management of village budgeting but the internal control system has a significant positive effect on financial management of village budgeting. Accountability financial statement of village as a intervening variable can mediate effect of the financial statement presentation and internal control system to financial management of village budgeting, but can not mediate the effect of the accessibility of financial statements to financial management of village budgeting,

Keywords : financial statement, accessibility of financial statements, internal control system, accountability of the financial statements, financial management of village budgeting.
\end{abstract}

\begin{abstract}
Abstrak
Penelitian ini bertujuan untuk menganalisis pengaruh laporan keuangan dan sistem pengendalian internal terhadap penyusunan anggaran dana desa dengan menggunakan akuntabilitas dana desa sebagai variabel intervening. Hasil penelitian menunjukkan bahwa penyajian laporan keuangan dan aksesibilitas laporan keuangan tidak berpengaruh terhadap penyusunan anggaran dana desa sedangkan sistem pengendalian internal berpengaruh positif signifikan terhadap penyusunan anggaaran dana desa. Akuntabilitas dana desa sebagai variabel intervening mampu memediasi pengaruh penyajian laporan keuangan dan sistem pengendalian internal terhadap penyusunan anggaran dana desa, namun tidak dapat memediasi pengaruh aksesibilitas laporan keuangan terhadap penyusunan anggaran dana desa.
\end{abstract}

Kata Kunci: laporan keuangan, aksesibilitas laporan keuangan. sistem pengendalian internal, akuntabilitas dana desa, penyusunan anggaran dana desa. 


\section{PENDAHULUAN}

\section{Latar Belakang}

Perkembangan desa di Indonesia selama lima tahun terakhir mengalami peningkatan. Perkembangan desa ini tidak lepas juga dari dikeluarkannya Undang-Undang no. 6 tahun 2014 yang lazim disebut sebagai Undang-Undang Desa. Adanya Undang-Undang Dana Desa membawa angin segar sehingga diharapkan kesejahteraan masyarakat desa dapat meningkat sesuai potensi yang dimilikinya. Pembangunan yang baik ditunjang dengan sarana dan prasarana yang memadai. Peningkatan sarana dan prasarana desa dapat dipenuhi dengan Dana Desa yang diterima oleh desa.

Dana Desa bersumber dari APBN. Peraturan Pemerintah No. 60 tahun 2014 tentang Dana Desa mengatur tentang Penyusunan anggaran untuk Dana Desa, (Makalalag et al, 2016). Dana desa yang dianggarkan tidak untuk digunakan bagi kebutuhan yang konsumtif melainkan untuk prasarana yang meningkatkan kesejahteraan masyarakat seperti pembangunan embung, sarana olahraga, peningkatan fasilitas umum,dan pemberdayaan kegiatan masyarakat untuk peningkatan ekonomi, (boyolali.go.id, 2019).

Sejumlah desa di Kabupaten Boyolali pada tahun 2017 masih menyisakan jatah pencairan Dana Desa. Sampai akhir Januari 2018 untuk dana desa tahun 2017 dari jatah Rp. 207,8 miliar baru terserap sejumlah Rp. 197.827.046.057 atau sebesar 95,19\%, sedangkan sisanya masih bisa dicairkan tergantung pada desa penerima. Kebanyakan dari desa tersebut belum menyampaikan kelengkapan administrasi pencairan dana, baik Anggaran Pendapatan dan Belanja Desa (APBDes) dan Rencana Kerja Pembangunan Desa (RKPD). Terhambatnya penyaluran dana desa akan sangat berpengaruh terhadap pembangunan desa dan kinerja aparat pemerintah desa, (https://jatengprov.go.id). Namun demikian pada tahun 2019 pemerintah menambah jumlah anggaran untuk Dana Desa di Kabupaten Boyolali sebesar Rp. 27 milyar atau sebesar 14\%. Penambahan jumlah ini diharapkan dapat memberikan pengaruh besar pada pembangunan desa di Kabupaten Boyolali, (http://boyolali.go.id). 
Pelaporan penggunaan dana secara transparan dan sesuai dengan aturan yang berlaku merupakan salah satu bentuk pertanggungjawaban atas dana yang telah digunakan. Dalam hal dana desa maka masyarakat berhak mengetahui penggunaan dana desa yang dikelola oleh pemerintah desa, (Mardiasmo, 2019). Tidak menutup kemungkinan bahwa masyarakat akan memberikan feetback berupa evaluasi kepada pemerintah desa atas pelaksanaan kegiatan yang didanai oleh dana desa. Penelitian Mustofa, (2012), Wardana, (2016) serta Utami (2019), menunjukkan bahwa penyajian laporan keuangan berpengaruh positif terhadap akuntabilitas dana desa. Penelitian Riyansa (2015), dan Yuliani (2017), menyatakan bahwa penyajian laporan keuangan tidak berpengaruh terhadap akuntabilitas.

Laporan keuangan selain harus transparan, terbuka, jujur dan sesuai dengan aturan yang ditetapkan ketika menyusunnya juga memberikan syarat agar laporan keuangan tersebut mudah diakses oleh penggunanya, (Mustofa 2012). Salah satu bentuk aksesibilitas yang bisa digunakan untuk pelaporan penggunaan desa adalah melalui media masa seperti suratkabar, televise majalah atau buletin desa, papan pengumuman, on line (web desa). Penelitian Hehanusa (2015), Wardana (2016), serta Utami (2019), menunjukkan bahwa aksesibilitas laporan keuangan berpengaruh positif terhadap akuntabilitas dana desa. Berbeda dengan hasil penelitian Yuliani, (2017), yang menyatakan bahwa aksesibilitas laporan keuangan tidak berpengaruh terhadap transparansi laporan keuangan.

Pengendalian internal merupakan suatu proses yang berfungsi memberikan arahan tentang bagaimana suatu proses harus berjalan sesuai dengan kebijakan yang ada dan dilaksanakan demi tercapainya tujuan organisasi secara optimal. Pengendalian internal disusun secara terstruktur sebagai suatu sistem. Dalam hal dana desa, maka pengendalian internal ditujukan kepada pemerintah desa yang tujuannya agar pelaksanaan kegiatan yang didanai oleh dana desa dapat berjalan terarah sesuai dengan sistem yang ada. Sistem Pengendalian Internal Pemerintah (SPIP) diatur dalam Peraturan Penerintah No. 60 tahun 2008. Sistem Pengendalian internal yang baik akan mendukung tercapainya tujuan organisasi yang efektif dan efisien serta pelaporan keuangan yang relevan dan andal, 
(Wardana, 2016). Krismiaji, (2010) menyebutkan bahwa pengendalian adalah rencana organisasi dan metode yang digunakan untuk melindungi sejumlah aktiva dan menghasilkan informasi yang akurat dan dapat dipercaya. Penelitian yang dilakukan oleh Ramon (2014), Widyatama et al, (2017), serta Utami (2019) menunjukkan bahwa Sistem Pengendalian berpengaruh positif terhadap akuntabilitas dana desa.

Akuntabilitas akan lebih efektif bila laporan yang disampaikan mudah dipahami oleh masyarakat dan pemerintah. Demikian pula dengan pelaporan dana desa, pelaporan keuangan yang mudah dipahami oleh masyarakat akan membuat masyarakat paham akan isi laporan, sehingga dengan demikian pemerintah desa telah melakukan tanggungjawabnya untuk memberikan informasi kegiatan yang didanai oleh dana desa. Akuntabilitas adalah salah satu kewajiban yang harus dipenuhi dan dipertanggungjawabkan pada proses perencanaan dan pelaksanaan, (Utami, 2016).

Sumber dari penyusunan anggaran dana desa adalah dari Anggaran Pendapatan dan Belanja Negara (APBN) yang diperuntukkan bagi Desa dan Desa Adat. APBN akan mentransfer dana desa melalui Anggaran Pendapatan dan Belanja Daerah Kabupaten/kota.Penyusunan anggaran dana desa merupakan salah satu proses perencanaan, sehingga akuntabilitas dana desa sangat diperlukan pada saat penyusunan anggaran desa, (Utami 2016).

Penelitian ini mengungkap faktor-faktor yang mempengaruhi penyusunan anggaran dana desa dilihat dari sisi laporan keuangan dan sistem pengendalian internal dengan menggunakan akuntabilitas dana desa sebagai intervening.

\section{TINJAUAN PUSTAKA}

\section{Teori Stewardship}

Penelitian ini menjelaskan bahwa pemerintah desa (steward) akan bertindak sesuai dengan kepentingan masyarakat (principal) dan bukan hanya pada kepentingan pihak yang duduk di pemerintahan desa.

Dalam penelitiaan ini, teori stewardship menggambarkan keberadaan pemerintah desa sebagai suatu organisasi yang dapat dipercaya dan bertindak sesuai aturan dan mempertanggungjawabkan ke kepentingan publik. Bentuk 
pertanggungjawaban pemerintah desa yang dapat ditunjukkan adalah membuat laporan keuangan secara transparan, akuntabel, dan sesuai aturan serta menyampaikannya ke publik, (Wardana, 2016).

\section{Penyusunan Anggaran Dana Desa}

Penyusunan anggaran merupakan suatu proses pembuatan rencana kerja berjangka waktu satu tahun yang dinyatakan dalam satuan moneter, (Husnayetti, 2012).

Sumber dari penyusunan anggaran dana desa adalah dari Anggaran Pendapatan dan Belanja Negara (APBN) yang diperuntukkan bagi Desa dan Desa Adat. APBN akan mentransfer dana desa melalui Anggaran Pendapatan dan Belanja Daerah Kabupaten/kota, (http://diskominfotik.bengkaliskab.go.id).

\section{Akuntabilitas}

Akuntabilitas merupakan suatu prinsip keterbukaan. Segala kegiatan yang telah dilaksanakan, terutama yang berkaitan dengan penggunaan suatu dana harus dipertanggungjawabkan oleh pelaksana. Demikian pula dengan dana desa, maka pihak pemerintah desa sebagai pelaksana kegiatan yang didanai oleh dana desa wajib melaporkan semua penerimaan dan penggunaan dana. Penyampaian pertanggungjawaban tersebut bukan hanya kepada pihak yang berwajib dalam hal ini adalah tingkat pemerintahan yang lebih tinggi namun juga kepada masyarakat, (Hidayah dan Wijayanti, 2017).

\section{Laporan Keuangan}

IAI-KASP (2015) menjelaskan bahwa membuat laporan keuangan merupakan tahap akhir dari siklus akuntansi. BPKP (2015) menyatakan laporan keuangan yang harus dibuat oleh pemerintah desa antara lain :

1. Laporan Realisasi Pelaksanaan APBDes

2. Pertanggungjawaban Realisasi Pelaksanaan APBDes

3. Laporan Realisasi Penggunaan Dana Desa

4. Laporan Pertanggungjawaban Realisasi Pelaksanaan APBDes

Peraturan Pemerintah No.71 Tahun 2010 tentang Standar Akuntansi Pemerintah (SAP) menjelaskan tentang karakteristik laporan keuangan pemerintah daerah. Karakteristik tersebut adalah sebagai berikut : 
1. Relevan

2. Andal

3. Dapat dibandingkan

4. Dapat dipahami

\section{Aksesibilitas Laporan Keuangan}

Aksesibilitas laporan keuangan merupakan salah satu bentuk dari pertanggungjawaban atas penggunaan suatu dana yang harus dikomunikasikan kepada pengguna informasi secara transparan , (Mardiasmo, 2010).

Dalam Peraturan Menteri Dalam Negeri No. 113 disebutkan bahwa akses tersebut diberikan oleh media cetak (surat kabar, majalah, dll), media elektronik (radio, televisi, dll), dan website (internet), serta forum yang memberikan peranan dan perhatian langsung yang mendorong akuntabilitas pemerintah terhadap masyarakat (Shende dan Bennet, 2004).

\section{Sistem Pengendalian Internal}

Pemerintah desa dapat mengerahkan semua kemampuannya untuk mengefektifkan pengendalian internal sehingga pada akhirnya dapat menghasilkan laporan keuangan yang berkualitas, dan transparan sebagai bentuk salah satu pelayanan kepada public, (Utami, 2016). Peraturan Pemerintah No. 60 Tahun 2008 mengatur tentang Sistem Pengedalian Internal Pemerintah (SPIP) di Indonesia.

\section{Pengembangan Hipotesis}

H1: Penyajian laporan keuangan berpengaruh positif terhadap akuntabilitas dana desa.

H2: Aksesibilitas laporan keuangan berpengaruh positif terhadap akuntabilitas dana desa.

H3: Sistem pengendalian internal berpengaruh positif terhadap akuntabilitas dana desa.

H4: Penyajian laporan keuangan berpengaruh positif terhadap penyusunan anggaran dana desa

H5: Aksesibilitas laporan keuangan berpengaruh positif terhadap penyusunan anggaran dana desa 
H6 : Sistem Pengendalian internal berpengaruh positif terhadap penyusunan anggaran dana desa

H7 : Akuntabilitas dana desa berpengaruh positif terhadap penyusunan anggaran dana desa

\section{Model Penelitian}

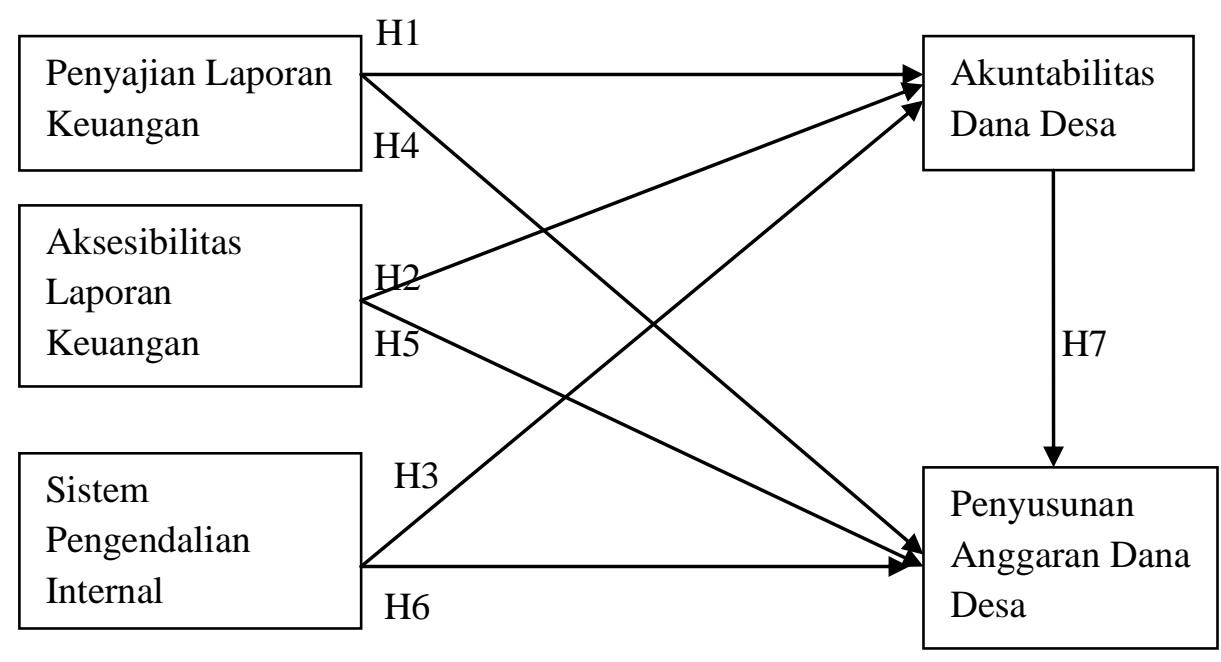

Gambar 1. Model Penelitian

\section{Metode Penelitian}

\section{Populasi dan Sampel}

Populasi yang digunakan dalam penelitiaan ini adalah seluruh desa di Kabupaten Boyolali yang terdiri dari 261 desa. Pengambilan sampel dilakukan dengan metode random sampling dimana pada masing-masing kecamatan (19 Kecamatan di Kabupaten Boyolali) akan diambil sebanyak satu sampai dua desa secara acak. Pada penelitian ini menggunakan sampel sebanyak 28 desa.

\section{Metode Pengumpulan Data}

Pengumpulan data dilakukan dengan penyebaran kuesioner mengenai penyusunan anggaran dana desa. Kuesioner tersebut diisi oleh aparat pemerintah desa yang berkaitan dengan dana desa. Terdapat 119 responden yang mengisi kuesioner dan akan menjadi data dalam penelitian ini. Skala yang digunakan dalam kuesioner ini adalah skala Likert dengan poin $1-5$. 


\section{Hasil dan Pembahasan}

\section{Uji Reliabilitas}

Kuesioner yang digunakan dalam penelitian ini telah lolos dalam uji reliabilitas dan uji validitas. Kriteria suatu kuesioner dikatakan reliabel bila nilai Cronbach Alpha > 0,6. Nilai Cronbach'Alpha untuk penyajian laporan keuangan adalah sebesar 0.750; aksesibilitas laporan keuangan sebesar 0.726; sistem pengendalian internal sebesar 0.623; akuntabilitas dana desa sebesar 0.737; penyusunan anggaran dana desa sebesar.

\section{Uji Validitas}

Suatu kuesioner dikatakan valid jika nilai correlated Item- Total Correlation $>0,176$. Uji validitas untuk pertanyaan-pertanyaan pada kuesioner yang digunakan dalam penelitian ini mempunyai nilai correlated Item- Total Correlation untuk semua pertanyaan $>0.176$ sehingga dapat dikatakan bahwa kuesioner yang digunakan adalah valid.

\section{Uji Asumsi Klasik}

\section{Uji Normalitas}

Uji Normalitas dalam penelitian ini menggunakan uji Kolmogorov Smirnov. Tabel 4 menunjukkan bahwa kolmogorov-smirnov mempunyai nilai signifikansi sebesar 0.088 di mana nilai tersebut diatas tingkat signifikan 0.05 , dengan demikian dapat disimpulkan bahwa data variabel yang di uji melalui model regresi ini telah berdistribusi dengan normal.

Tabel 1. Uji Normalitas dengan Kolmogorov Smirnov

One-Sample Kolmogorov-Smirnov Test

\begin{tabular}{|ll|r|}
\hline & & $\begin{array}{c}\text { Unstandardized } \\
\text { Residual }\end{array}$ \\
\hline Normal Parameters ${ }^{\mathrm{a}, \mathrm{b}}$ & & 119 \\
& Mean & .0000000 \\
Most Extreme Differences & Std. Deviation & 1.32930630 \\
& Absolute & .115 \\
& Positive & .115 \\
Kolmogorov-Smirnov Z & Negative & -.050 \\
Asymp. Sig. (2-tailed) & & 1.251 \\
& & .088 \\
\hline
\end{tabular}

a. Test distribution is Normal.

b. Calculated from data. 
Tabel 1 menunjukkan bahwa kolmogorov-smirnov mempunyai nilai signifikansi sebesar 0.088 di mana nilai tersebut diatas tingkat signifikan 0.05 , dengan demikian dapat disimpulkan bahwa data variabel yang di uji melalui model regresi ini telah berdistribusi dengan normal.

\section{Uji Multikolinearitas}

Tabel 2. Uji Multikolinearitas

Coefficients $^{\mathrm{a}}$

\begin{tabular}{|c|c|c|c|c|c|c|c|c|}
\hline \multirow{2}{*}{\multicolumn{2}{|c|}{ Model }} & \multicolumn{2}{|c|}{$\begin{array}{l}\text { Unstandardized } \\
\text { Coefficients }\end{array}$} & \multirow{2}{*}{\begin{tabular}{|c|}
$\begin{array}{c}\text { Standardized } \\
\text { Coefficients }\end{array}$ \\
Beta
\end{tabular}} & \multirow[b]{2}{*}{$\mathrm{t}$} & \multirow[b]{2}{*}{ Sig. } & \multicolumn{2}{|c|}{$\begin{array}{c}\text { Collinearity } \\
\text { Statistics }\end{array}$} \\
\hline & & $B$ & Std. Error & & & & Tolerance & VIF \\
\hline \multirow[t]{5}{*}{1} & (Constant) & 4.547 & 1.626 & & 2.797 & .006 & & \\
\hline & Penyajian Lap & .077 & .084 & .082 & .915 & .362 & .694 & 1.441 \\
\hline & Aksbt Lap Keu & .134 & .064 & .175 & 2.106 & .037 & .800 & 1.250 \\
\hline & Sist pengd intr & .274 & .092 & .275 & 2.996 & .003 & .655 & 1.527 \\
\hline & Akuntbl Dana Ds & .265 & .080 & .286 & 3.333 & .001 & .750 & 1.333 \\
\hline
\end{tabular}

a. Dependent Variable: Penysn Agr Dana Ds

Berdasarkan tabel di atas peroleh hasil bahwa nilai tolerance masingmasing variabel $>$ dari 0.1 . Nilai VIF $<10$. Dapat disimpulkan bahwa seluruh variabel bebas pada penelitian ini tidak ada gejala multikolinearitas.

\section{Uji Heteroskedastisitas}

Berdasarkan hasil pengolahan data untuk uji heteroskedastisitas didapatkan nilai sig untuk semua variabel $>0.05$. Nilai Sig untuk penyajian laporan keuangan sebesar 0.168, nilai sig untuk aksesibilitas laporan keuangan sebesar 0.384, dan nilai sig untuk system pengendalian internal sebesaar 0.148. Hal tersebut menyimpulkan bahwa data yang digunakan dalam penelitian ini tidak terjadi heteroskedastisitas dan data layak digunakan.

\section{Uji Autokorelasi}

Berdasarkan hasil pengolahan data untuk uji autokorelasi, nilai DurbinWatson menunjukkan angka sebesar 1,961. Menurut Al Gifari (2000) bila nilai Durbin Watson di antara 1,66-2,34 maka data terbebas dari autokorelasi, sehingga dapat disimpulkan bahwa data dalam penelitian ini tidak terjadi autokorelasi di dalam regresi. 


\section{Koefisien Determinasi}

Dari hail pengolahan data diketahui bahwa besarnya nilai Adjusted $R^{2}$ diperoleh sebesar 0.230. Maka berarti variabel dependen dapat dipengaruh oleh variabel independen sebesar 23\%. Hal ini menunjukkan bahwa $77 \%$ variabel akuntabilitas dana desa dipengaruhi oleh variabel lain di luar variabel independen yang digunakan dalam penelitian ini.

\section{Uji Goodness of Fit (Kelayakan Model)}

Berdasarkan tabel 3 di bawah, hasil dari uji ANOVA atau F test didapat nilai signifikansi probabilitas sebesar 0.000 , karena probabilitas jauh lebih kecil dari 0,05 atau 5\% maka model regresi dapat digunakan dalam kerangka pikir teoritis atau layak (fit) untuk digunakan.

\section{Tabel 3. Uji Goodness of fit}

\begin{tabular}{|ll|r|r|r|r|r|}
\hline \multicolumn{7}{|c|}{ ANOVA $^{\mathbf{0}}$} \\
\hline 1 & Sum of Squares & Df & Mean Square & \multicolumn{1}{c|}{ F } & Sig. \\
\hline & Regression & 88.718 & 4 & 22.179 & 16.826 & $.000^{\mathrm{a}}$ \\
& Residual & 150.274 & 114 & 1.318 & & \\
& Total & 238.992 & 118 & & & \\
\hline
\end{tabular}

a. Predictors: (Constant), Akuntbl Dana Ds, Aksbt Lap Keu, Penyajian Lap, Sist pengd intr

b. Dependent Variable: Penysn Agr Dana Ds

\section{Uji Hipotesis}

\section{Uji t}

\section{Tabel 4. Hasil uji t}

\begin{tabular}{|l|l|l|l|}
\hline \multicolumn{1}{|c|}{ Hipotesis } & \multicolumn{1}{c|}{ Sig } & \multicolumn{1}{c|}{ Kesimpulan } \\
\hline Hipotesis 1 & 2.461 & 0.015 & Hipotesis 1 diterima, hipotesis 0 ditolak \\
\hline Hipotesis 2 & -0.419 & 0.676 & Hipotesis 2 ditolak, hipotesis 0 diterima \\
\hline Hipotesis 3 & 3.881 & 0.000 & Hipotesis 3 diterima, hipotesis 0 ditolak \\
\hline Hipotesis 4 & 1.633 & 0.105 & Hipotesis 4 ditolak, hipotesis 0 diterima \\
\hline Hipotesis 5 & 1.896 & 0.060 & Hipotesis 5 ditolak, hipotesis 0 diterima \\
\hline Hipotesis 6 & 4.211 & 0.000 & Hipotesis 6 diterima, hipotesis 0 ditolak \\
\hline Hipotesis 7 & 5.859 & 0.000 & Hipotesis 7 diterima, hipotesis 0 ditolak \\
\hline
\end{tabular}

Sumber : Data yang diolah

1. Penyajian laporan keuangan berpengaruh positif signifikan terhadap akuntabilitas dana desa. Hal ini dapat dilihat dari nilai Sig sebesar 0,015 yang $<0,05$ sehingga dapat dikatakan bahwa $\mathrm{H} 1$ diterima dan $\mathrm{H} 0$ ditolak. 
2. Aksesibilitas laporan keuangan tidak berpengaruh terhadap akuntabilitas dana desa. Hal ini dapat dilihat dari nilai Sig sebesar 0,676 yang >0,05, sehingga dapat dikatakan bahwa $\mathrm{H} 2$ ditolak dan $\mathrm{H} 0$ diterima.

3. Sistem pengendalian internal berpengaruh positif terhadap akuntabilitas dana desa. Hal ini dapat dilihat dari nilai Sig sebesar 0,000 yang $<0,05$ sehingga dapat dikatakan bahwa $\mathrm{H} 3$ diterima dan $\mathrm{H} 0$ ditolak.

4. Penyajian laporan keuangan tidak berpengaruh terhadap penyusunan anggaran dana desa. Hal ini dapat dilihat dari nilai Sig sebesar 0,105 yang > 0,05 sehingga dapat dikatakan bahwa $\mathrm{H} 4$ ditolak dan $\mathrm{H} 0$ diterima.

5. Aksesibilitas laporan keuangan berpengaruh positif signifikan terhadap penyusunan anggaran dana desa. Hal ini dapat dilihat dari nilai Sig sebesar 0,060 yang > 0,05, sehingga dapat dikatakan bahwa H5 ditolak dan H0 diterima.

6. Sistem pengendalian internal berpengaruh positif signifikan terhadap penyusunan anggaran dana desa. Hal ini dapat dilihat dari nilai Sig sebesar 0,000 yang < 0,05 sehingga dapat dikatakan bahwa H3 diterima dan H0 ditolak.

7. Akuntabilitas dana desa berpengaruh positif signifikan terhadap penyusunan anggaran dana desa. Hal ini dapat dilihat dari nilai Sig seesar 0.000 yang < 0,005, sehingga dapat dikatakan bahwa $\mathrm{H} 7$ diterima dan $\mathrm{H} 0$ ditolak.

\section{Sobel Tes}

Tabel 5. Sobel Tes

\begin{tabular}{|l|l|l|l|}
\hline \multicolumn{1}{|c|}{ Keterangan } & \multicolumn{1}{|c|}{$\begin{array}{c}\text { Sobel test } \\
\text { statistic }\end{array}$} & \multicolumn{1}{c|}{$\begin{array}{c}\text { One-tailed } \\
\text { probability }\end{array}$} & \multicolumn{1}{c|}{$\begin{array}{c}\text { Two-tailed } \\
\text { probability }\end{array}$} \\
\hline Hasil Uji sobel tes I & 2.27703208 & 0.01139216 & 0.02278431 \\
\hline Hasil Uji sobel tes II & -0.41232047 & 0.34005227 & 0.68010455 \\
\hline Hasil Uji sobel tes III & 3.24140155 & 0.00059472 & 0.00118944 \\
\hline
\end{tabular}

Sumber : Data yang diolah

Dari tabel 8 dapat dilihat bahwa:

1. Nilai uji sobel tes I sebesar 2.27703208 dimana nilai tersebut $>1,96$ sehingga dapat dikatakan bahwa akuntabilitas dana desa dapat menjadi intervening 
untuk pengaruh penyajian laporan keuangan terhadap penyusunan anggaran dana desa.

2. Nilai sobel tes sebesar -0.41232047 di mana nilai tersebut $<1,96$ sehingga dapat dikatakan bahwa akuntabilitas dana desa tidak dapat menjadi intervening untuk pengaruh aksesibilitas laporan keuangan terhadap penyusunan anggaran dana desa.

3. Nilai sobel tes sebesar 3.24140155 di mana nilai tersebut $>1,96$ sehingga dapat dikatakan bahwa akuntabilitas dana desa dapat menjadi intervening untuk pengaruh sistem pengendalian internal terhadap penyusunan anggaran dana desa.

\section{Pembahasan}

Penyajian laporan keuangan yang disajikan tepat waktu, lengkap dan dapat memberikan informasi yang bermanfaat untuk pengambilan keputusan merupakan bentuk dari pertanggungjawaban yang harus disampaikan oleh pengelola dana. Hal tersebut menunjukkan bahwa akuntabilitas telah berjalan dengan baik. Hasil penelitian ini sejalan dengan hasil penelitian yang dilakukan oleh Mustofa, (2012), Wardana, (2016) serta Utami (2019).

Hasil penelitian menunjukkan bahwa aksesibilitas laporan keuangan tidak berpengaruh terhadap akuntabilitas dana desa. Hal ini disebabkan karena masih banyak desa di kabupaten Boyolali yang belum menyampaikan laporan keuangan yang berkaitan dengan Dana Desa dengan menggunakan media masa seperti koran desa, majalah desa, radio, dan website. Penyampaian laporan Dana Desa kepada masyarakat kebanyakan hanya melalui Informasi Penyelenggaraan Pemerintah Desa (IPPD) berupa MMT yang ditempelkan di dinding kantor desa sehingga bagi masyarakat yang tidak menyempatkan diri datang ke kantor desa tidak akan mengetahui bagaimana pelaporan keuangan Dana Desa. Hasil penelitian ini tidak sesuai dengan penelitian yang dilakukan oleh Hehanusa (2015), Wardana (2016), serta Utami (2019),

Hasil penelitian menunjukkan bahwa sistem pengendalian internal berpengaruh positif terhadap akuntabilitas dana desa. Sistem pengendalian internal yang baik akan membantu terciptanya kondisi tertib, efektif dan efisien, 
taat pada peraturan perundang-undangan yang berlaku sehingga pengambilan keputusan yang tepat dapat diambil. Hal inipun berlaku pada pertanggungjawaban dana desa yang dikelola oleh pemerintah desa. Hasil penelitian ini sesuai dengan penelitian yang dilakukan oleh Ramon (2014), Widyatama et al, (2017), serta Utami (2019).

Hasil penelitian menunjukkan bahwa penyajian laporan keuangan tidak berpengaruh terhadap penyusunan anggaran dana desa. Penyusunan anggaran dana desa untuk periode berikutnya tidak mengacu sepenuhnya dari laporan keuangan yang telah dilaporkan pada periode sebelumnya. Hal ini disebabkan karena anggaran disusun sesuai dengan kebutuhan yang akan datang dan program yang akan dijalankan bisa berbeda dengan program tahun sebelumnya. sehingga penyajian laporan keuangan periode sebelumnya tidak menjadi dasar sepenuhnya untuk penyusunan anggaran berikutnya. Hasil penelitian ini tidak sesuai dengan penelitian yang dilaksanakan oleh Utami, (2019).

Hasil penelitian menunjukkan bahwa aksesibilitas laporan keuangan tidak berpengaruh terhadap penyusunan anggaran dana desa. Penyusunan anggaran dana desa periode berikutnya tidak bergantung pada kemudahan pengguna untuk mengakses laporan keuangan dana desa periode sebelumnya. Penyusunan anggaran dana desa adalah suatu kegiatan yang ditujukan untuk kegiatan di masa depan, sedangkan aksesibilitas laporan keuangan adalah kegiatan yang dilaksanakan untuk menyampaikan laporan keuangan masa lalu. Hasil penelitian ini tidak sesuai dengan penelitian yang dilakukan oleh Wardana, (2016).

Hasil penelitian menunjukkan bahwa sistem pengendalian internal berpengaruh positif signifikan terhadap penyusunan anggaran dana desa. Adanya sistem pengendalian internal akan menuntun penyusunan anggaran dana desa untuk lebih terarah, dan disusun sesuai dengan peraturan dan perundang-undangan yang ada, sehingga kegiatan yang dianggarkan akan efektif dan efisien. Hasil penelitian ini sesuai dengan pernyataan yang disampaikan oleh Aramide dan Bashir, (2015).

Hasil penelitian menunjukkan bahwa akuntabilitas dana desa berpengaruh positif signifikan terhadap penyusunan anggaran dana desa. Pada saat proses 
perencanaan, akuntabilitas merupakan kewajiban yang harus dipenuhi dan dipertanggungjawabkan. Salah satu proses perencanaan adalah penyusunan anggaran dalam hal ini adalah anggaran dana desa, dengan kata lain akuntabilitas akan berpengaruh terhadap penyusunan anggaran dana desa. Hasil penelitian ini sesuai dengan yang disampaikan oleh Utami, (2019).

Hasil penelitian menunjukkan bahwa secara langsung penyajian laporan keuangan tidak berpengaruh terhadap penyusunan anggaran dana desa, namun dengan adanya akuntabilitas dana desa sebagai variabel intervening maka penyajian laporan keuangan termediasi terhadap penyusunan anggaran dana desa.

Hasil penelitian menunjukkan bahwa aksesibilitas laporan keuangan tidak berpengaruh terhadap penyusunan anggaran dana desa. Akuntabilitas dana desa juga tidak mampu memediasi pengaruh aksesibilitas laporan keuangan terhadap penyusunan anggaran dana desa.

Hasil penelitian menunjukkan bahwa secara langsung sistem pengendalian internal berpengaruh terhadap penyusunan anggaran dana desa. Akuntabilitas dana desa sebagai variabel intervening juga mampu memediasi pengaruh sistem pengendalian internal terhadap penyusunan anggaran dana desa.

\section{Simpulan}

Simpulan dalam penelitian ini adalah :

1. Penyajian laporan keuangan berpengaruh positif signifikan terhadap akuntabilitas dana desa.

2. Aksesibilitas laporan keuangan tidak berpengaruh terhadap akuntabilitas dana desa.

3. Sistem pengendalian internal berpengaruh positif signifikan terhadap akuntabilitas dana desa.

4. Penyajian laporan keuangan tidak berpengaruh terhadap penyusunan anggaran dana desa.

5. Aksesibilitas laporan keuangan tidak berpengaruh terhadap penyusunan anggaran dana desa.

6. Sistem pengendalian internal berpengaruh positif signifikan terhadap penyusunan anggaran dana desa. 
7. Akuntabilitas dana desa berpengaruh positif signifikan terhadap penyusunan anggaran dana desa.

8. Akuntabilitas dana desa memediasi pengaruh penyajian laporan keuangan terhadap penyusunan anggaran dana desa.

9. Akuntabilitas dana desa tidak memediasi pengaruh aksesibilitas laporan keuangan terhadap penyusunan anggaran dana desa.

10. Akuntabilitas dana desa memediasi pengaruh sistem pengendalian internal terhadap penyusunan anggaran dana desa.

\section{Saran}

1. Menambah variabel bebas lainnya yang dianggap berpengaruh terhadap penyusunan anggaran dana desa karena nilai koefisien determinasi masih relative kecil.

2. Memperluas dan menambah jumlah sampel penelitian sehingga hasil penelitian akan lebih optimal.

3. Mencoba variabel lain sebagai variabel intervening sehingga diharapkan hasil penelitian lebih baik.

\section{ACKNOWLEDGMENTS}

Penelitian ini didukung dan dibiayai sepenuhnya oleh Penelitian Dosen Pemula Kementerian Riset, Teknologi dan Pendidikan Tinggi (RISTEKDIKTI) Republik Indonesia tahun 2019.

\section{DAFTAR PUSTAKA}

Badan Pengawasan Keuangan dan Pembangunan, 2015, Petunjuk Pelaksanaan Bimbingan dan Konsultasi Keuangan Desa, Deputi Bidang Pengawasan Penyelenggaraan Keuangan Daerah

Ghozali, I., 2013, Aplikasi Analisis Multivariate dengan Program IBM SPSS 21, Badan Penerbit Universitas Diponegoro, Semarang

Hehanusa, Salomi J., 2015. Pengaruh Penyajian Laporan Keuangan Daerah Dan Aksesibilitas Laporan Keuangan Daerah Terhadap Transparasi Dan Akuntabilitas Pengelolaan Keuangan Daerah Kota Ambon. Jurnal Fakultas Ekonomi Universitas Kristen Indonesia Maluku. 
Hidayah, Nurul; Wijayanti, Iin, 2017, Akuntabilitas Pengelolaan Dana Desa (DD) Studi Kasus pada Desa Wonodadi Kecamatan Ngrayun Kabupaten Ponorogo, Jurnal AKSI (Akuntansi dan Sistem Informasi), Vol. 2 Edisi 1, September 2017

https://jatengprov.go.id

https://boyolali.go.id

http://diskominfotik.bengkalis.go.id

Husnayetti, 2012, Anggaran Perusahaan, Jelajah Nusa, Tangerang.

Ikatan Akuntan Indonesia - KSAP, 2015, Pedoman Asistensi Akuntansi Keuangan

Mardiasmo, 2010, Akuntansi Sektor Publik, CV. Andi Offset, Yogyakarta

Mustofa, Anies Iqbal. 2012. Pengaruh Penyajian dan Aksesibilitas Laporan Keuangan terhadap Akuntabilitas Pengelolaan Keuangan Kabupaten Pemalang. Accounting Analysis Journal. ISSN 2252-6765. Universitas Negeri Semarang

. 2008. Peraturan Pemerintah No. 60 tentang Sistem Pengendalian Internal Pemerintah (SPIP).

. 2010. Peraturan Pemerintah No.71 tentang Standar Akuntansi Pemerintah (SAP).

. 2014 Peraturan Pemerintah No. 60 tentang Dana Desa

. 2014. Peraturan Menteri Dalam Negeri Nomor 113 tentang Pengelolaan Keuangan Desa.

Ramon, Dolly. 2014. Pengaruh Sistem Pengendalian Internal terhadap Akuntabilitas Keuangan (Studi Empiris Pada Inspektorat Kota Se Provinsi Sumatera Barat). Jurnal Akuntansi Fakultas Ekonomi Universitas Bung Hatta.

Riyansa, Ridho; Yunilma dan Fauziati, Poppy, 2015, Pengaruh Penyajian Laporan Keuangan dan Aksesibilitas aporan Keuangan terhadap Akuntabilitas Pengelolaan Keuangan Daerah (Studi Empiris pada Pemerintah Kabupaten Padang Pariaman), Jurnal Akuntansi, Fakultas Ekonomi Universitas Bung Hatta. 
Shende, Suresh; Bennet, Tony, 2004, Concept Paper 2, Transparancy and Accountability in Public Financial Administration, UN DESA 2014. Undang-Undang No.6 tentang Desa.

Utami, Resti, 2019, Pengaruh Penyajian Laporan Keuangan, Aksesibilitas Laporan Keuangan dan Sistem Akuntansi Keuangan Daerah terhadap Ketepatan Pengelolaan Keuangan Daerah pada Pemerintah Kota Pontianak, Jurnal MAKSI, Vol 4 No. 1, Universitas Tanjungpura, Pontianak

Wardana, Ibnu, 2016, Akuntabilitas dalam Pengelolaan Keuangan Desa (Studi pada Pemerintah Desa di Kabupaten Magelang), Universitas Negeri Semarang.

Widyatama, Arif; Novita, Lola; Diarespati, 2017, Pengaruh Kompetensi dan Sistem Pengendalian Internal terhadap Akuntabilitas Pemerintah Desa dalam Mengelola Alokasi Dana Desa (ADD), BAKI (Berkala Akuntansi dan Keuangan Indonesia), Vol 2, No. 2.

Yuliani, Nul Laila, 2017, Pengaruh Penyajian Laporan Keuangan, Karakteristik Kualitatif, Aksesibilitas dan Pengendalian Internal terhadap Transparansi Laporan Keuangan Pemerintah Daerah, Jurnal Bisnis dan Ekonomi (JBE), Vol 24, No. 1, Maret, 2017. 